\title{
Silurian-Early Devonian mafic rocks of the Piscataquis volcanic belt in northern Maine
}

\author{
R. Hon, J.P. Fitzgerald, S.L. Sargent, W.D. Schwartz \\ Department of Geology and Geophysics, Boston College, Chestnut Hill, Massachussetts 02167, U.S.A. \\ J. Dostal \\ Department of Geology, Saint Mary's University, Halifax, Nova Scotia B3H 3C3, Canada \\ and \\ J.D. Keppie \\ Nova Scotia Department of Mines and Energy, P.O. Box 1087, Halifax, Nova Scotia B3J 2X1, Canada
}

Date Received July 8, 1991

Date Accepted November 13, 1991

\begin{abstract}
The Silurian-Early Devonian eruptive rocks at selected sites in the Piscataquis volcanic belt in northern Maine are composed of mafic and felsic rocks with rare intermediate types. The mafic rocks are mainly basalts that are commonly strongly fractionated and have the characteristics of intraplate continental tholeiites. The mantlenormalized incompatible trace element patterns of the rocks display negative $\mathrm{Nb}$-Ta anomalies that were probably inherited from sub-continental lithosphere modified by pre-Silurian subduction processes. However, they do not have Ti depletion typical of subduction-related magmas. On the other hand, the youngest (late Early Devonian) Edmunds Hill Formation is composed of calc-alkali andesites that exhibit features typical of arc-related magmas. The SilurianEarly Devonian volcanic rocks were primarily erupted in a within-plate extensional environment that terminated with limited subduction. This extensional environment is inferred to be associated with the sinistral accretion of the Avalon Composite Terrane that produced an oblique pull-apart rift in adjacent Laurentia.
\end{abstract}

Les roches érutives du Silurien et du Dévonien précoce provenant de sites choisis dans la ceinture volcanique de Piscataquis du Maine septentrional sont composées de roches mafiques et felsiques avec de rares termes intermédiaires. Les roches mafiques sont principalement des basaltes qui sont communément différenciés et qui présentent les caractéristiques des tholéiites continentales intraplaques. Les patrons d'éléments traces normalisés par le manteau pour les roches mafiques montrent des anomalies négatives en $\mathrm{Nb}$ et $\mathrm{Ta}$ qui furent probablement héritées de la lithosphère sous-continentale modifiée par des processus de subduction pré-siluriens. Cependant, elles ne présentent pas d'appauvrissement en Ti typique des magmas reliés à la subduction. Par ailleurs, la Formation d'Edmunds Hill, qui est la plus jeune (fin du Dévonien précoce), est composée d'andésites calco-alcalines présentant des caractéristiques typiques des magmas reliés aux arcs. Les roches volcaniques du Silurien et du Dévonien précoce firent éruption dans un environnement intraplaque extensionnel qui se termina par une composante mineure de subduction. On déduit que cet environnement extensionnel est associé à l'accrétion senestre du terrain composite d'Avalon qui produisit un rift de décrochement oblique dans le terrain de Laurentia adjacent.

[Traduit par le journal]

\section{INTRODUCTION}

The Piscataquis volcanic belt is broadly defined as a zone of discontinuous suites of Silurian-Early Devonian volcanic rocks that lie within the Connecticut Valley-Gaspé Synclinorium in Maine and adjacent Quebec (Fig. 1). Originally this definition was restricted to rhyolitic members of the Moose River and Traveler Mountain region (locality 1 on Fig. 1) (Rankin, 1968). However, it has been expanded to include all the other volcanic suites of similar age within the same tectonic domain (Osberg et al., 1989). To the northeast, the Piscataquis volcanic belt merges with the Tobique volcanic belt that extends from the Gaspe Peninsula along the northwestern margin of the Miramichi Highlands in New
Brunswick (Bedard, 1986; Dostal et al., 1989). To the southwest, the Piscataquis volcanic belt apparently dies out although some isolated occurrences of Early Devonian volcanic rocks occur in western New Hampshire and central Vermont.

The volcanic rocks are mainly of Late Silurian and Early Devonian age with a few ranging down to Early Silurian. They are interbedded with and grade laterally into sedimentary rocks that form part of a Silurian-Devonian overstep sequence deposited unconformably across the North American craton and several accreted Cambrian-Ordovician terranes (Keppie, 1989). Coeval intrusive bodies with ages ranging between 415 and $375 \mathrm{Ma}$ occur in the Greenville plutonic belt (lying just south of the Piscataquis volcanic belt), be- 


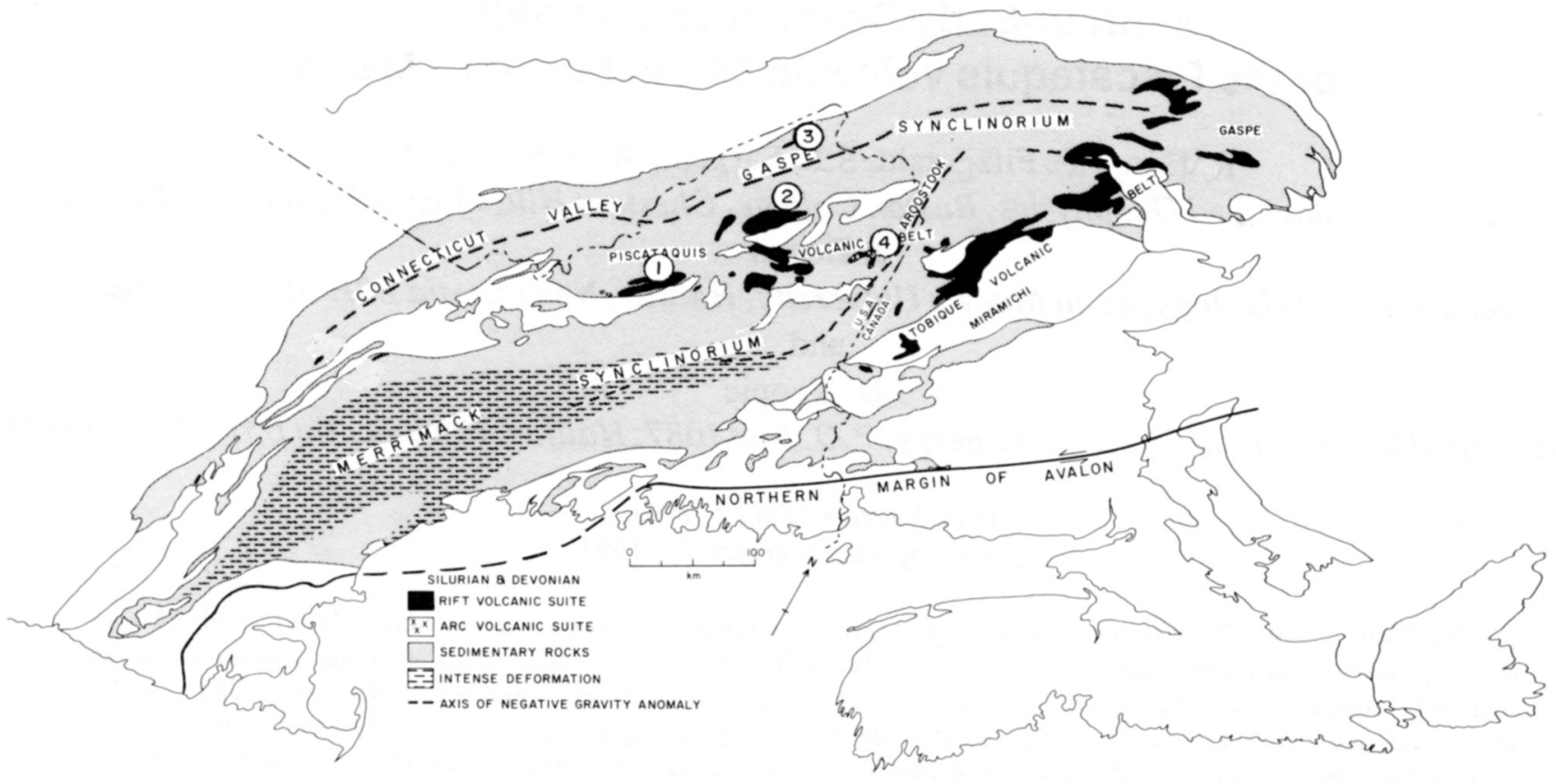

Fig. 1. Map of the northern part of the mainland Appalachians showing the distribution of Silurian-Devonian volcanic and sedimentary rocks, associated negative Bouguer anomalies and a region of most intense Devonian deformation. Numbers 1 to 4 show the locations of analyzed mafic volcanic rocks and the stratigraphic columns shown in Figure 2.

tween the Piscataquis and Tobique volcanic belts (Osberg $e t$ $a l ., 1985$ ) and in the Miramichi Highlands (Bevier and Whalen, 1989).

The Silurian-Early Devonian Piscataquis rocks have commonly been interpreted as a volcanic arc built upon the edge of cratonic North America related to the Acadian convergence and subduction (e.g., Rankin, 1968; Bradley, 1983; Thirwall, 1988). However, recent studies on equivalent volcanic rocks of the Tobique volcanic belt in New Brunswick and Gaspé have shown that the basalts were erupted in a continental rifting environment in an orogenic foreland (Laurent and Belanger, 1984; Bedard, 1986; Dostal et al., 1989). This brings into question the nature of the Piscataquis volcanic belt. This paper presents geochemical data for the Silurian-Devonian rocks of the Piscataquis volcanic belt in Maine which indicate that most of them were also erupted in a continental rift environment.

\section{Geological Setting}

The Piscataquis volcanic belt is generally envisaged to have formed a string of volcanic centres that provided local detritus to the neighbouring sedimentary basins: the Connecticut Valley-Gaspé trough to the north and the MatapediaAroostook-Merrimack trough to the south (Osberg et al., 1989). The Silurian rocks of the Connecticut Valley-Gaspé trough in Maine and adjacent Quebec consist of a southeastward thickening sequence (ca. 1000 to $5500 \mathrm{~m}$ ) of shallow marine shelf sedimentary rocks. They have been subdivided into Lower Silurian basal lithic wacke and conglomerate, shale, tuff and minor volcanic rocks overlain by Upper
Silurian sandstone, limestone, shale, volcanic rocks, siltstone and conglomerate (Boucot, 1968; Lajoie et al., 1968). The rocks of the Matapedia-Aroostook-Merrimack trough in Maine consist of beach and reef deposits (sandstone, conglomerate and limestone) fringing local volcanic centres in the Piscataquis volcanic belt that grade quickly southward into ca. 5000 to $6000 \mathrm{~m}$ thick turbidite fans (wacke and shale) interrupted in places by graphitic shale, limestone and well-sorted sandstone (Pavlides, 1974; Roy and Mencher, 1976).

The Silurian rocks of the Connecticut Valley-Gaspé and Matapedia-Aroostook-Merrimack troughs are overlain by Lower Devonian flysch derived from northeastern, eastern and southeastern sources in such abundance that it supplied detritus to both troughs (Boucot et al., 1964; Hall et al., 1976). Rock types grade from sandstone along the basin margins through interbedded shale and limestone to wacke and shale in the basin centres. The presence of the Lower Devonian sandstone wedges suggest coalescing deltas (ca. $260 \mathrm{~m}$ thick) which grade westwards into prodelta marine slope deposits up to $4000 \mathrm{~m}$ thick (Hall et al., 1976).

Volcanic rocks are exposed over a distance of about 160 $\mathrm{km}$ along the axis of the Piscataquis volcanic belt (Fig. 1) and reach a thickness of $3000 \mathrm{~m}$. The three main sections of Silurian-Devonian rocks examined in this study are located in the Katahdin, Spider Lake and Presque Isle areas with a subsidiary section in the Fivemile Brook region (Figs. 1, 2).

In the Katahdin area (Figs. 1,2), the basal Lower Silurian conglomerate is overlain by interbedded sandstone and limestone containing the latest Llandoverian or Wenlockian fossils. These are succeeded by the Ripogenus Formation which consists of twelve mafic flows interbedded with calcareous 


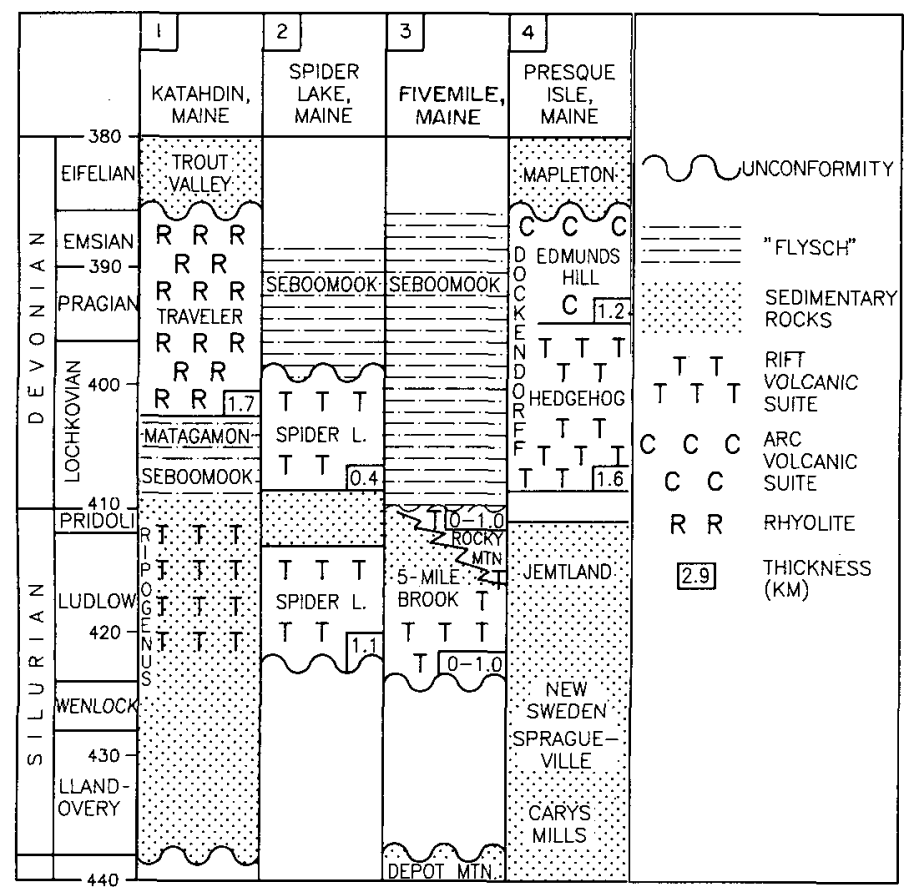

Fig. 2. Stratigraphic correlation chart for selected localities along the Piscataquis volcanic belt (1-4 cross referenced with Figure 1).

beds of probable Ludlovian and Pridolian age. The rocks are overlain by either shallow marine fossiliferous, Early Devonian sandstone or the facies equivalent flysch of the Lower Devonian Seboomook and Matagamon formations that are, in turn, overlain by thick predominantly welded ash flows of the Traveler and its lateral equivalent Kineo rhyolites. The Traveler and Kineo rhyolites were erupted from several large volcanic centres, such as the Traveler caldera (Rankin and Hon, 1987). They are typically aphanitic with lithic clasts of rhyolite, diabase, sandstone and shale, and contain small phenocrysts of quartz (in the lower member only), feldspar and locally pyroxene and biotite. Intrusive equivalents of the Traveler rhyolite have been dated at $388 \pm 5 \mathrm{Ma}$ (U-Pb zircon from Katahdin pluton: Loiselle et al., 1983), and $375 \pm 3 \mathrm{Ma}$ $\left({ }^{40} \mathrm{Ar}{ }^{\beta 9} \mathrm{Ar}\right.$ mineral analyses from Horserace pluton: Denning and Lux, 1985). The Traveler rhyolite is unconformably overlain by the late Early to Middle Devonian Trout Valley Formation. These rocks have suffered only minor effects of deformation and metamorphism.

The Spider Lake Formation (Figs. 1, 2) consists of about $3200 \mathrm{~m}$ of subaqueous-subaerial basalts and pyroclastic rocks interbedded with basal conglomerate, fossiliferous shale, sandstone and massive limestone outcropping over an area of about $800 \mathrm{~km}^{2}$ (Osberg et al., 1985). The basaltic lava flows range in thickness from 0.5 to $10 \mathrm{~m}$, are commonly massive with vesicular flow tops, and contain phenocrysts of pyroxene and plagioclase set in a groundmass composed of plagioclase, clinopyroxene and $\mathrm{Fe}$-Ti oxides. Pillow lavas are rare. Fossils in the Spider Lake Formation indicate that it spans the Ludlovian and lowermost Devonian (Hall, 1970). The Spider Lake Formation is overlain by flysch of the Seboomook
Formation. The whole sequence was gently folded and metamorphosed to sub-greenschist facies.

The northernmost outlier of volcanic rocks examined in this paper occur in the Fivemile Brook area of northern Maine (Figs. 1, 2). The Fivemile Brook Formation concordantly overlies the Caradocian-middle Llandoverian Depot Mountain Formation apparently with a minor hiatus (Roy, 1989). The shallow marine Fivemile Brook Formation consists of interlayered phyllite, limestone, basalt (2-31 m thick flows) and contains Ludlovian fossils. This formation is generally in fault contact with the overlying Early Devonian flysch of the Seboomook Formation. Locally, the Rocky Mountain quartz latite laterally replaces the Fivemile Brook Formation (Roy, 1989). It consists of ca. $1000 \mathrm{~m}$ of predominantly felsic lithic and crystal tuff with minor intercalated basalt. The Fivemile Brook mafic rocks range from the aphanitic types with vesicles or amygdules to porphyritic varieties containing plagioclase and clinopyroxene phenocrysts. The groundmass of the aphanitic rocks and associated minor intrusions have subophitic to intersertal textures composed of plagioclase, clinopyroxene and Fe-Ti oxides. The amygdules are generally filled with calcite rimmed by chlorite and epidote. The rocks have suffered open folding and sub-greenschist facies metamorphism.

The Dockendorff Group is exposed in an outlier at the eastern end of the Piscataquis volcanic belt in the Presque Isle area (Figs. 1, 2). In this area, Upper Ordovician-Lower Silurian calcareous slate, wacke and limestone of the Carys Mills Formation are conformably overlain by clastic to calcareous mudstone, and these are, in turn, overlain by turbidites of the late Middle Silurian Jemtland Formation (Roy and Mencher, 1976). All of these units are overlain by the Lower Devonian units: Hedgehog Formation (ca. $1600 \mathrm{~m}$ thick succession of mafic volcanic rocks succeeded by predominant rhyolites and tuffs) and the Edmunds Hill Formation (ca. $1200 \mathrm{~m}$ of andesite). The mafic flows of the Hedgehog Formation are fine-grained and commonly contain feldspar phenocrysts. The Hedgehog rhyolites are typically eutaxitic ignimbrites with crystal and vitric tuffs that contain both quartz and feldspar phenocrysts, and welded pumice fragments set in a vitroclastic matrix consisting mainly of quartz, feldspars and accessory Fe-Ti oxides, biotite and apatite. These rocks are associated with tuffs that may contain vesicles, lithic fragments and feldspar crystals. The secondary minerals of the felsic rocks include sericite, epidote, chlorite and calcite. The overlying Edmunds Hill andesite is divisible into a lower pyroxene-bearing member and an upper biotitebearing member (Boucot et al., 1964). The lower member contains phenocrysts of feldspar and pyroxene in a pilotaxitic matrix, whereas the upper member is darker in colour and has hyalopilitic texture. The Dockendorff Group was deformed by open folds accompanied by prehnite-pumpellyite metamorphism (Richter and Roy, 1976) before being unconformably overlain by clastic sedimentary rocks of the late Middle Devonian Mapleton Formation (White and Roy, 1975). 


\section{GeOChemistry}

\section{Sampling and Analytical Methods}

Mafic volcanic rocks form a small proportion of the volcanic rocks of the Piscataquis belt. However, because of their crucial role in determining the tectonic setting, they were preferentially selected for analyses for this paper. Systematic sampling of the volcanic rocks at each locality was followed by the petrographic investigation to select the lavas for chemical analyses. A total of 96 lava samples were analyzed. Detailed sample locations, individual petrographic descriptions and complete analytical data are available in Fitzgerald (1991), Sargent (1985) and Schwartz (1991). Representative analyses are presented in Table 1.

The major element compositions of the samples from the Dockendorff area were determined by atomic absorption at Boston College. Major elements in the other samples were analyzed by $\mathrm{X}$-ray fluorescence. The trace elements $\mathrm{Rb}, \mathrm{Ba}$, $\mathrm{Sr}, \mathrm{Y}, \mathrm{Zr}, \mathrm{Nb}, \mathrm{Zn}, \mathrm{Ni}, \mathrm{Cr}$ and $\mathrm{V}$ were determined by $\mathrm{X}$-ray fluorescence while the instrumental neutron activation technique was employed for the determination of the rare-earth elements (REE), Sc, Th, Ta, Hf and $\mathrm{Co}$. The analytical error for the trace element analyses is generally smaller than 5\%. The X-ray fluorescence analyses were done at Saint Mary's University while neutron activation data were obtained in Boston College.

\section{Alteration}

Although every effort was made to acquire the freshest possible samples, all of the volcanic rocks are affected to some degree by alteration processes. The alteration effects are manifested particularly by elevated contents of LOI and the scatter of alkalies. Most other elements do not appear to be significantly affected by alteration because they retain concentrations that are similar to those of recent volcanic suites. Furthermore, the least altered rocks generally have chemical compositions similar to rocks which are extensively replaced by secondary minerals. This similarity indicates that the present contents of most elements of the rocks approximate the primary magmatic concentrations.

\section{Whole-Rock Geochemistry}

The Silurian-Devonian extrusive rocks in the Piscataquis volcanic belt show considerable diversity (Fig. 3; Table 1). In the Katahdin area, basalts of the Ripogenus Formation are overlain by Traveler and Kineo dacites and rhyolites. On the other hand, the Spider Lake and Fivemile Brook formations are composed predominantly of basalts with rare andesites. In the Presque Isle area, the Devonian Hedgehog Formation composed of a bimodal basalt-rhyolite sequence is overlain by andesitic lavas of the Edmunds Hill Formation.

The mafic and intermediate rocks can be divided into two distinct types: (1) intraplate basalts with subordinate basaltic andesites and andesites (Katahdin, Spider Lake, Fivemile Brook areas and Hedgehog Formation); (2) exclusively subduction-related andesites with $\sim 60 \% \mathrm{SiO}_{2}$ (Edmunds Hill Formation).

The intraplate mafic rocks are mainly basalts with about 48 to $53 \% \mathrm{SiO}_{2}$ (on LOI-free basis) and have variable $\mathrm{Mg}$ \#'s (mole $\mathrm{Mg} / \mathrm{Mg}+\mathrm{Fe}$ ) indicating extensive fractional crystallization. The basalts display typical tholeiitic fractionation

Table 1. Chemical composition of representative Silurian-Early Devonian mafic rocks of the Piscataquis belt.

\begin{tabular}{|c|c|c|c|c|c|c|c|c|c|c|c|c|c|c|c|c|c|c|c|c|c|}
\hline & \multicolumn{5}{|c|}{ KATAHDIN } & \multicolumn{4}{|c|}{ SPIDER LAKE } & \multicolumn{4}{|c|}{ FIVE MILE } & \multicolumn{4}{|c|}{ HEDGEHOG } & \multicolumn{4}{|c|}{ EDMUNDS HILL } \\
\hline & $\mathbf{R P}-2$ & RP-3 & RP-6 & RP-7 & $R P-4$ & SP-14 & SP-21 & SP-24 & SP-28 & 7 & 17 & 21 & 18 & 145 & 209 & 208 & 206 & 69 & 228 & 233 & 216 \\
\hline $\mathrm{SiO}_{2}(\%)$ & 50.75 & 51.27 & 51.67 & 51.28 & 56.76 & 49.26 & 48.47 & 48.39 & 49.24 & 50.92 & 50.08 & 51.91 & 55.55 & 50.66 & 52.47 & 55.12 & 54.39 & 63.36 & 61.60 & 61.91 & 63.67 \\
\hline $\mathrm{TiO}_{2}$ & 3.29 & 3.19 & 3.12 & 3.52 & 1.77 & 2.19 & 1.91 & 2.09 & 2.68 & 1.78 & 2.08 & 1.97 & 2.24 & 1.36 & 1.65 & 1.71 & 1.92 & 0.83 & 0.91 & 0.94 & 0.88 \\
\hline $\mathrm{Al}_{2} \mathrm{O}_{3}$ & 13.60 & 13.78 & 13.89 & 13.72 & 14.33 & 15.59 & 16.36 & 16.96 & 15.05 & 16.80 & 18.09 & 16.77 & 14.75 & 17.21 & 15.45 & 15.55 & 15.07 & 16.41 & 16.71 & 16.40 & 16.90 \\
\hline $\mathrm{Fe}_{2} \mathrm{O}$, & 13.44 & 13.73 & 13.37 & 13.47 & 8.71 & 12.47 & 11.70 & 11.58 & 12.90 & 10.82 & 11.37 & 10.27 & 10.12 & 8.30 & 9.42 & 9.74 & 10.93 & 5.13 & 6.20 & 5.81 & 5.25 \\
\hline MnO & 0.23 & 0.23 & 0.20 & 0.20 & 0.14 & 0.20 & 0.17 & 0.19 & 0.18 & 0.14 & 0.14 & 0.12 & 0.21 & 0.17 & 0.17 & 0.15 & 0.18 & 0.08 & 0.11 & 0.09 & 0.12 \\
\hline $\mathrm{MgO}$ & 4.35 & 4.07 & 5.77 & 4.58 & 4.06 & 6.78 & 7.87 & 7.63 & 6.25 & 3.03 & 7.17 & 4.15 & 3.04 & 5.69 & 5.30 & 3.92 & 3.52 & 2.08 & 2.82 & 2.74 & 1.25 \\
\hline $\mathrm{CaO}$ & 7.69 & 6.50 & 6.89 & 6.48 & 6.97 & 8.70 & 9.03 & 7.52 & 9.36 & 13.56 & 4.99 & 7.64 & 6.99 & 12.37 & 10.51 & 8.47 & 6.50 & 6.86 & 6.27 & 6.67 & 6.17 \\
\hline $\mathrm{Na}_{2} \mathrm{O}$ & 5.34 & 5.59 & 3.44 & 5.39 & 6.32 & 3.38 & 4.00 & 4.01 & 3.55 & 1.28 & 5.63 & 6.46 & 5.81 & 3.36 & 3.90 & 4.16 & 5.23 & 4.32 & 3.91 & 4.08 & 4.84 \\
\hline $\mathrm{K}_{2} \mathrm{O}$ & 0.64 & 0.91 & 1.26 & 0.94 & 0.67 & 1.11 & 0.24 & 1.31 & 0.36 & 1.22 & 0.20 & 0.30 & 0.68 & 0.64 & 0.86 & 0.86 & 1.76 & 0.82 & 1.22 & 1.12 & 0.55 \\
\hline $\mathrm{P}_{2} \mathrm{O}_{3}$ & 0.67 & 0.72 & 0.40 & 0.42 & 0.27 & 0.31 & 0.25 & 0.32 & 0.44 & 0.45 & 0.25 & 0.41 & 0.61 & 0.24 & 0.27 & 0.31 & 0.50 & 0.10 & 0.23 & 0.23 & 0.37 \\
\hline LOI & 0.67 & 1.10 & 1.20 & 4.20 & 3.88 & 3.51 & 4.09 & 4.07 & 6.20 & $<3.0$ & $<3.0$ & $<3.0$ & $<3.0$ & 8.20 & 9.81 & 7.99 & 1.72 & 4.29 & 2.25 & 4.20 & 4.17 \\
\hline $\mathbf{M g}_{8}$ & 0.47 & 0.45 & 0.54 & 0.48 & 0.55 & 0.60 & 0.65 & 0.65 & 0.57 & 0.44 & 0.64 & 0.53 & 0.45 & 0.65 & 0.61 & 0.53 & 0.47 & 0.52 & 0.56 & 0.57 & 0.40 \\
\hline $\mathrm{Sc}(\mathrm{ppm})$ & 37.0 & 35.0 & 38.2 & 39.6 & 30.9 & 36.8 & 32.7 & 32.6 & 36.7 & 27.0 & 29.0 & 27.8 & 24.0 & 21.6 & 21.0 & 21.3 & 18.8 & 12.4 & 13.6 & 13.0 & 13.1 \\
\hline $\mathrm{v}$ & 389 & 360 & 374 & 420 & 248 & 299 & 242 & 275 & 349 & 186 & 201 & 195 & 178 & 195 & 208 & 225 & 188 & 82 & 104 & 105 & 85 \\
\hline Co & 32.0 & 47.5 & 42.6 & 34.9 & 26.7 & 42.8 & 43.5 & 44.7 & 35.9 & 38.0 & 42.0 & 32.7 & 21.0 & 30.0 & 25.0 & 22.0 & 23.0 & 14.5 & 15.1 & 15.7 & 12.1 \\
\hline $\mathrm{Cr}$ & 23 & 15 & 35 & 5 & nd & 168 & 192 & 170 & 99 & 153 & 140 & 125 & 18 & 143 & 104 & 101 & 11 & 23 & 40 & 35 & so \\
\hline $\mathrm{Ni}$ & 15 & iI & 23 & 13 & nd & 72 & 112 & 118 & 49 & 86 & 78 & 79 & 11 & 23 & 35 & 30 & 16 & 20 & 19 & 22 & 31 \\
\hline$Z_{n}$ & 110 & 123 & 131 & 111 & 66 & 103 & 94 & 97 & 131 & 78 & 91 & 89 & 104 & 63 & 103 & 90 & 75 & 62 & 66 & 62 & 65 \\
\hline Ga & 24 & 10 & 23 & 21 & 17 & 17 & 17 & 19 & 22 & 20 & 16 & 18 & 24 & 14 & 15 & 17 & 22 & 12 & 13 & 13 & 14 \\
\hline $\mathbf{R b}$ & 7 & 10 & 24 & 12 & $<s$ & 2 & 2 & 23 & 2 & 29 & 4 & 5 & 8 & 24 & 17 & 17 & 70 & is & 34 & 32 & 13 \\
\hline $\mathrm{Sr}$ & 282 & 205 & 274 & 102.0 & 201 & 270 & 234 & 358 & 201 & 396 & 465 & 310 & 570 & 636 & 522 & sis & 234 & 396 & 357 & 340 & 459 \\
\hline $\mathrm{Ba}$ & 363 & 268 & 326 & 172 & 225 & 703 & 74 & 1037 & 123 & 269 & 266 & 163 & 587 & 268 & 421 & 433 & 290 & 188 & 258 & 216 & 284 \\
\hline $\mathrm{Y}$ & 52 & 57 & 40 & 43 & 43 & 31 & 27 & 29 & 41 & 29 & 26 & 72 & 28 & 54 & 56 & 86 & 29 & 29 & 29 & 25 & \\
\hline $\mathrm{Zr}$ & 355 & 382 & 250 & 278 & 342 & 185 & 154 & 172 & 251 & 264 & 130 & 229 & 548 & 120 & 229 & 264 & 328 & 189 & 206 & 200 & 183 \\
\hline $\mathrm{Hf}$ & 8.29 & 9.05 & 6.52 & 7.18 & 8.41 & 4.63 & 3.55 & 3.92 & 6.58 & 5.30 & 3.00 & 5.40 & 13.0 & 3.24 & 5.31 & 5.96 & 7.30 & S.50 & 5.27 & 5.16 & 4.74 \\
\hline $\mathrm{Nb}$ & 11 & 14 & 8 & 9 & 9 & 6 & 8 & 9 & 8 & 7 & 4 & 7 & 16 & 9 & 8 & 11 & 14 & 10 & 13 & 11 & 10 \\
\hline $\mathbf{T a}$ & 0.88 & 0.89 & 0.60 & 0.62 & 0.58 & 0.33 & 0.25 & 0.40 & 0.47 & 0.49 & 0.27 & 0.56 & 1.08 & 0.34 & 0.30 & 0.43 & 0.57 & 0.65 & 0.69 & 0.70 & 0.67 \\
\hline Th & 3.27 & 3.71 & 1.95 & 2.85 & 5.34 & 1.49 & .68 & .60 & 2.07 & nd & nd & nd & nd & 2.70 & 3.40 & 4.17 & 5.07 & 7.68 & 5.76 & 5.50 & 6.10 \\
\hline $\mathbf{L a}$ & 27.5 & 30.9 & 19.2 & 20.3 & 22.8 & 13.5 & 10.6 & 11.6 & 18.8 & 18.5 & 7.8 & 23.6 & 36.6 & 16.9 & 17.8 & nd & 21.6 & 20.7 & 20.6 & 20.2 & 18.4 \\
\hline $\mathrm{Ce}$ & 66.2 & 74.2 & 47.1 & 49.7 & 55.2 & 32.9 & 26.2 & 28.9 & 46.5 & 46.0 & 22.4 & 49.6 & 93.0 & 37.6 & 39.2 & 44.3 & 50.8 & 52.3 & 43.8 & 44.0 & 37.1 \\
\hline Nd & 38.6 & 43.6 & 28.9 & 32.2 & 29.3 & 21.5 & 17.2 & 17.3 & 29.1 & 26.1 & 16.5 & 23.8 & 42.0 & 19.7 & 21.1 & nd & 31.2 & 20.6 & 20.1 & 20.5 & 18.5 \\
\hline $\mathrm{Sm}$ & 10.0 & 10.80 & 7.29 & 8.02 & 7.51 & 5.49 & 4.59 & 5.02 & 7.49 & 5.90 & 4.58 & 6.86 & 12.70 & 4.07 & 5.52 & nd & 7.31 & 4.08 & 3.85 & 3.67 & 3.52 \\
\hline Eu & 3.02 & 3.28 & 2.43 & 2.52 & 1.95 & 1.92 & 1.69 & 1.76 & 2.35 & 1.73 & 1.52 & 2.01 & 3.06 & 1.35 & 1.76 & 2.00 & 1.79 & nd & nd & nd & nd \\
\hline Gd & nd & nd & nd & nd & nd & nd & nd & nd & nd & nd & nd & nd & nd & 3.68 & 6.76 & 7.73 & 7.72 & 3.49 & 3.37 & 3.45 & 2.83 \\
\hline Tb & 1.46 & 1.81 & 1.00 & 1.14 & 1.11 & 0.72 & 0.61 & 0.68 & 1.02 & 0.92 & 0.70 & 0.91 & 1.88 & 0.65 & 1.24 & 1.34 & 1.45 & 0.63 & 0.63 & 0.58 & 0.50 \\
\hline$Y_{b}$ & 5.61 & 6.21 & 4.42 & 4.63 & 5.26 & 3.41 & 2.81 & 2.84 & 4.84 & 3.00 & 2.70 & 3.37 & 7.76 & 1.92 & 3.40 & nd & 4.98 & 2.03 & 2.03 & 1.94 & 1.67 \\
\hline Lu & 0.88 & 0.99 & 0.69 & 0.73 & 0.80 & 0.56 & 0.38 & 0.40 & 0.72 & 0.45 & 0.39 & 0.50 & 1.16 & 0.28 & $0 \Delta 9$ & nd & 0.76 & 0.32 & 0.31 & 0.30 & 0.26 \\
\hline
\end{tabular}



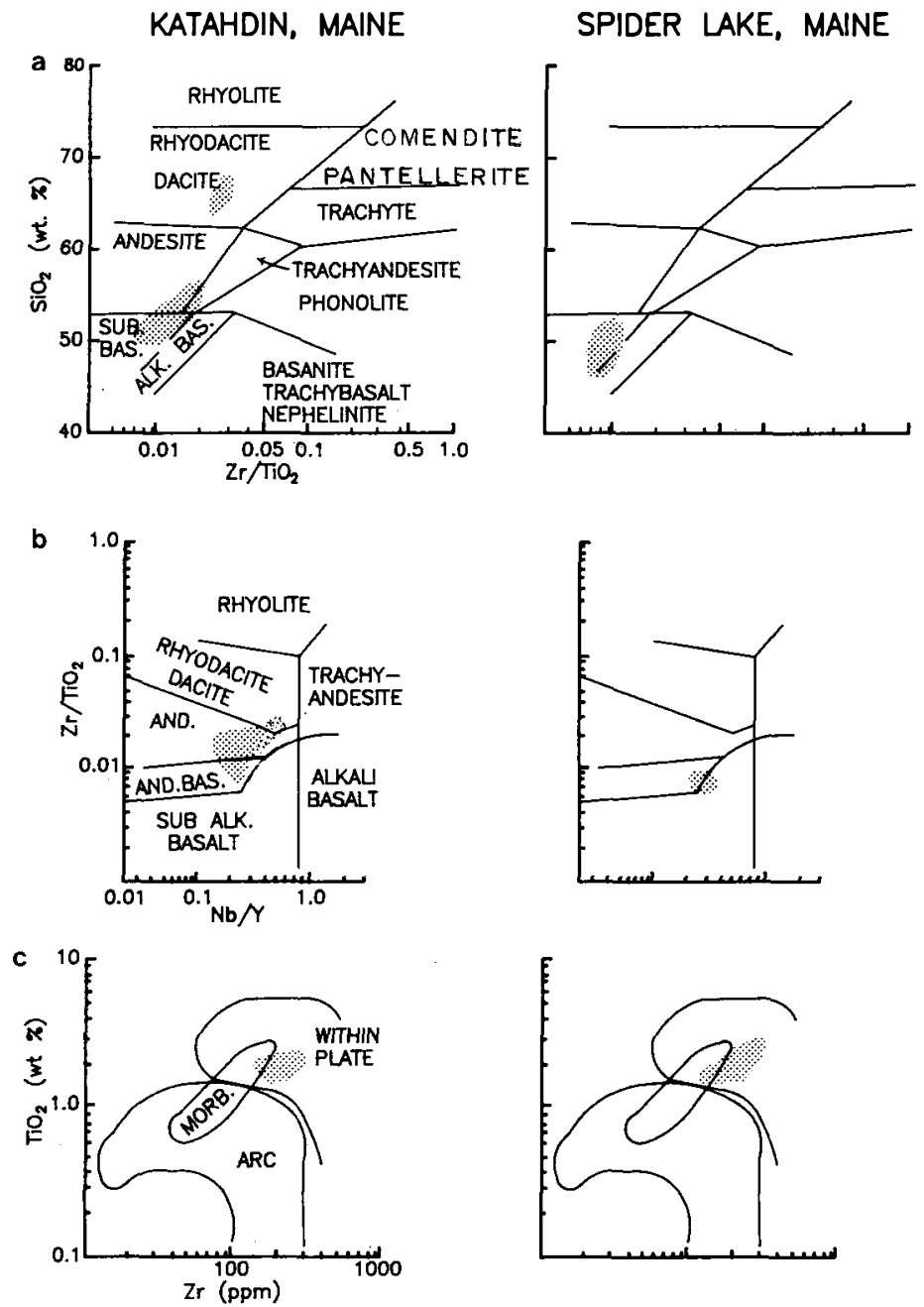

FIVEMILE, MAINE
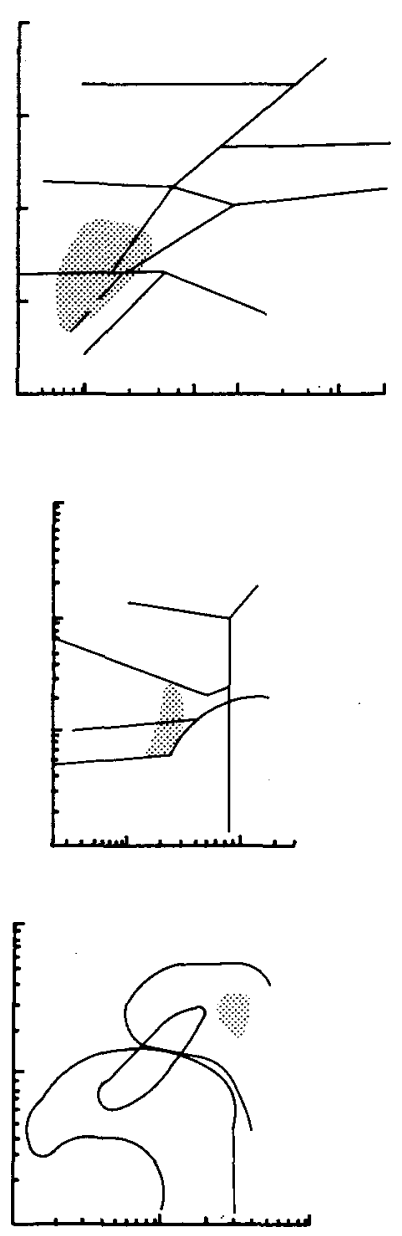

PRESQUE ISLE, MAINE
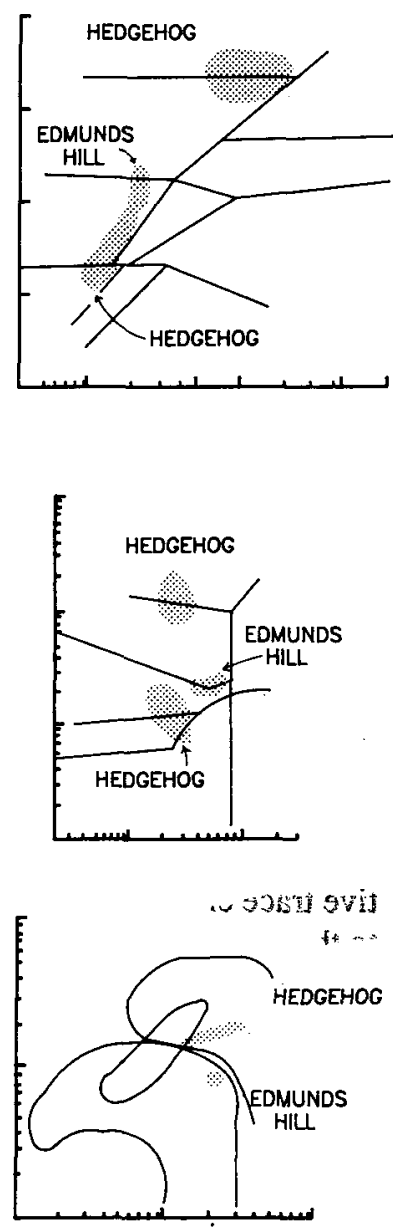

Fig. 3. Geochemical plots of volcanic rocks from the Piscataquis volcanic belt of northern Maine: (a) $\mathrm{Zr} / \mathrm{TiO} \mathrm{O}_{2}$ versus $\mathrm{SiO}_{2}$ (Winchester and Floyd, 1977) for all lavas; (b) $\mathrm{Zr} / \mathrm{TiO}_{2}$ versus $\mathrm{Nb} / \mathrm{Y}$ (Winchester and Floyd, 1977) for all lavas; (c) $\mathrm{Zr}$ versus $\mathrm{TiO}_{2}$ (Pearce, 1983) for basalts and andesites.

trends of increasing $\mathrm{Fe}$, Ti and $\mathrm{V}$ with differentiation which is accompanied by relatively high and constant $\mathrm{Ti} / \mathrm{V}$ ratios (Fig. 4) characteristic of within plate tholeiitic basalts (Shervais, 1982). The REE patterns (Fig. 5) are moderately enriched in light REE (LREE) with $\mathrm{La} / \mathrm{Yb}$ ratios mostly between $\sim 3$ and 5 although some samples have $\mathrm{La} / \mathrm{Yb}>10$. The strongly differentiated basalts and basaltic andesites have higher abundances of REE but their patterns are approximately parallel to those of basalts and show an Eu depletion. The mantle-normalized incompatible trace element plots (Fig. 6) show an enrichment of large-ion-lithophile-elements (LILE) relative to heavy REE and high-field-strength elements (HFSE) and exhibit distinct negative $\mathrm{Nb}$ and $\mathrm{Ta}$ anomalies. According to discrimination diagrams such as $\mathrm{Ti}$ versus $\mathrm{Zr}$ (Pearce, 1983), the basalts were emplaced in a withinplate environment (Fig. 3). All these geochemical characteristics are typical of strongly fractionated intraplate tholeiitic basalts emplaced on continental crust.

The Katahdin volcanic rocks (Ripogenus Formation) also contain rift andesitic lava flows and dacitic porphyry plugs. The andesites have $\mathrm{SiO}_{2}$ contents ranging from 54 to $58 \%$ and are distinct from calc-alkali equivalents in having higher contents of $\mathrm{TiO}_{2}$ (1.8-1.9\%) (Table 1). Their REE patterns are enriched in LREE with a flat HREE segment and La abundances about $70 x$ chondrites (Fig. 5). The shape of these REE profiles is similar to some basalt patterns. The basalts and andesites display continuous variation trends indicating that they are related and that fractional crystallization played an important role during their genesis. However, the differences between the basalts and andesites cannot be completely explained by a simple process of fractional crystallization and assimilation was probably an additional factor in their genesis.

The second type of mafic and intermediate rocks are represented solely by the andesites of the Edmunds Hill Formation. They have a relatively uniform composition with $\mathrm{SiO}_{2}$ between 60 and $64 \%$ (Fig. 3 ), $\mathrm{Mg} \#$ between 0.50 and 0.40. The abundances of incompatible trace elements are typical of those of subduction-related calc-alkali andesites erupted on relatively thin continental crust. The representa- 


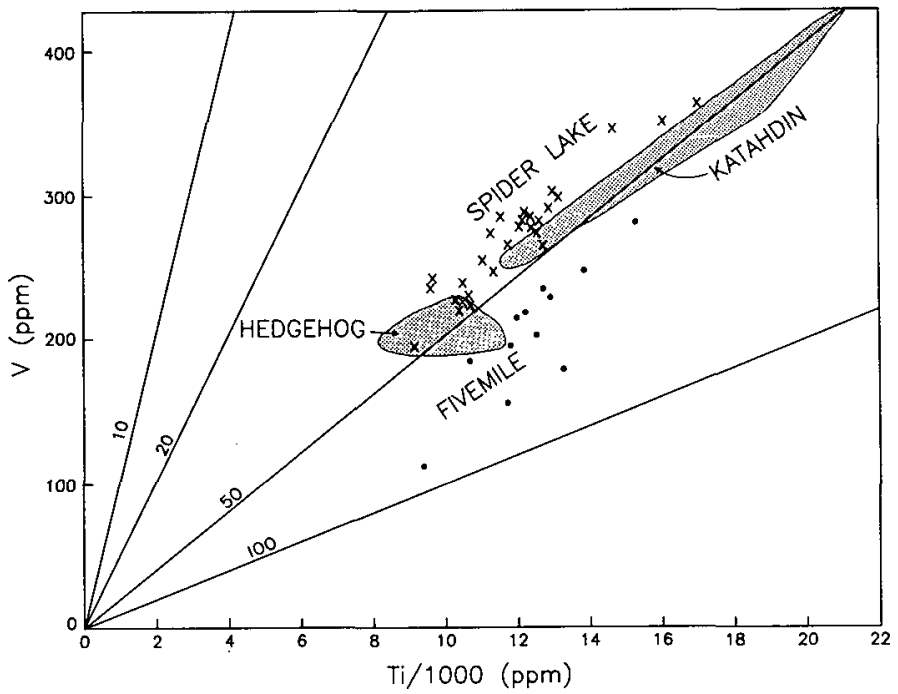

Fig. 4. Ti versus $V$ diagram of Shervais (1982) for the SilurianEarly Devonian basaltic rocks of the Piscataquis volcanic belts. The basalts have high $\mathrm{Ti} / \mathrm{V}$ ratios typical of non-orogenic magmas.

tive trace element abundances of andesitic lavas normalized to the primitive mantle of Sun and McDonough (1989) (Fig. 6) display patterns with LILE enrichment and depletions in HFSE, notably $\mathrm{Nb}$ and $\mathrm{Ta}$, relative to LILE and LREE. Compared to the patterns of the intraplate basalts (Fig. 6), the andesites also have a negative $\mathrm{Ti}$ anomaly, characteristic of arc magmas (Condie, 1987). The subduction-related character of the andesitic rocks is also shown on the Ti- $\mathrm{Zr}$ discrimination plot (Fig. 3). The REE patterns are enriched in LREE, show some HREE fractionation and have $\mathrm{La} / \mathrm{Yb}$ ratios around 10 (Fig. 5).

\section{Discussion}

\section{Petrogenesis}

The mafic extrusive rocks of the Silurian-Early Devonian Piscataquis volcanic belt are mainly intraplate tholeiitic basalts that are variably but commonly highly fractionated. Their composition is similar to many continental tholeiites including those of the Chaleur and Dalhousie groups of the Tobique belt of New Brunswick (Dostal et al., 1989). That the rocks were derived from a compositionally heterogeneous mantle probably by a variable degree of melting is indicated by (1) the variable abundances of incompatible trace elements in basaltic rocks of a given $\mathrm{Mg} \#$ with relatively uniform major element compositions, and (2) differences in incompatible trace element ratios such as $\mathrm{Zr} / \mathrm{Y}, \mathrm{La} /$ $\mathrm{Yb}$ and $\mathrm{Zr} / \mathrm{Nb}$. Their mantle-normalized incompatible trace element patterns show a distinct enrichment of LILE relative to HREE and HFSE accompanied by negative anomalies of $\mathrm{Nb}$ and $\mathrm{Ta}$. In contrast to typical arc samples (Condie, 1987), the rocks do not show a negative $\mathrm{Ti}$ anomaly. The $\mathrm{Nb}$ - $\mathrm{Ta}$ depletion that is frequently observed in continental tholeiites

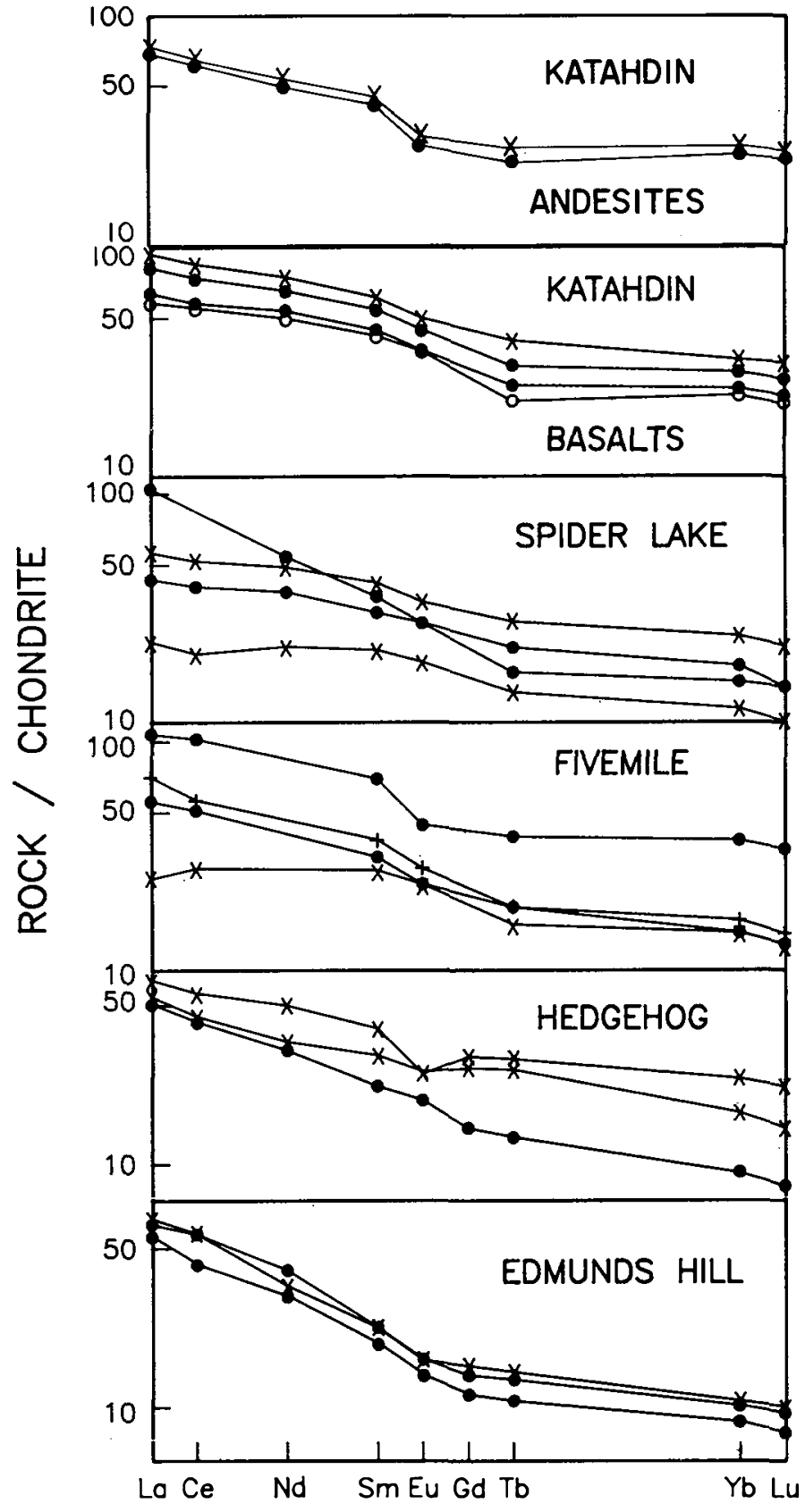

Fig. 5. Chondrite-normalized rare-earth element abundance patterns for representative basalts from each outcrop area in the Piscataquis volcanic belt and for representative Edmunds Hill andesites.

probably represents compositional characteristics inherited from the mantle source. The presence of $\mathrm{Nb}$ - Ta anomalies in the mantle source might be due to the involvement of a crustal component in the petrogenesis of the basalts and suggests a subcontinental lithospheric source for the basalts. This "crustal" signature may have been superimposed on the mantle during the incorporation of crustal material into the mantle by a pre-Silurian subduction process. Alternatively, the $\mathrm{Nb}$-Ta depletion could be due to crustal contamination of basaltic magmas.

The andesites of the Edmunds Hill Formation are calc- 


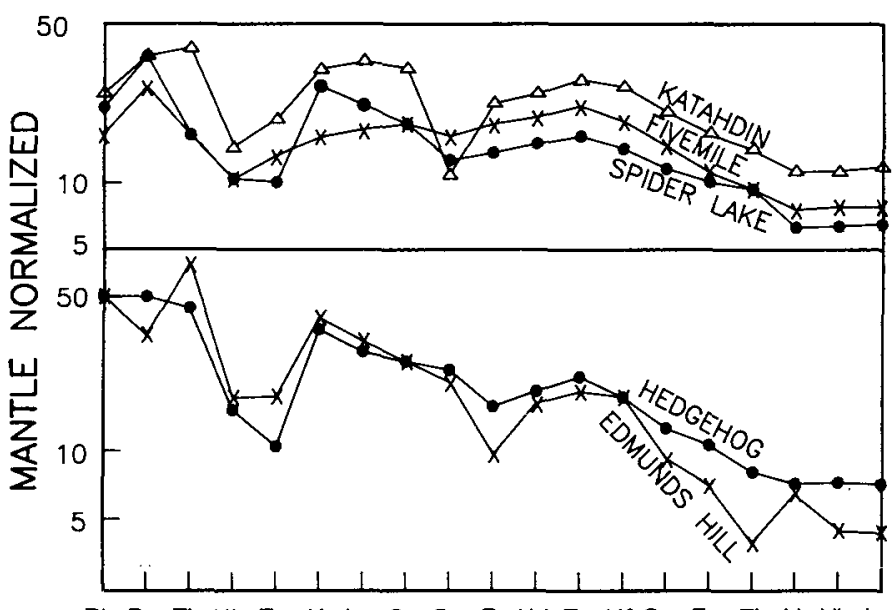

Rb Ba Th Nb Ta K La Ce Sr P Nd Zr Hf SmEu Ti Y Yb Lu

Fig. 6. Mantle-normalized trace element variation diagrams for the averages of the basaltic rocks from various units of the Piscataquis volcanic belt and the Edmunds Hill andesites. Normalizing values and the order of trace-element incompatibility are from Sun and McDonough (1989).

alkali and do not appear to be directly related to the tholeiitic basalts. The differences in the ratios of incompatible trace elements show that they were derived from a different source. The distribution of these elements is typical of subductionrelated magma (Condie, 1987; Wilson, 1989).

\section{Tectonic Significance}

With the exception of the Edmunds Hill andesites, the Silurian-Early Devonian volcanism in the Piscataquis volcanic belt took place in an extensional setting rather than in a volcanic arc (e.g., Bradley, 1983); a similar conclusion to that obtained on the rocks from the Tobique volcanic belt (Dostal et al., 1989). Calc-alkali arc volcanism is limited spatially and temporally to late Early Devonian Edmunds Hill andesites in the Presque Isle area.

The Silurian-Early Devonian volcanic rocks are part of an Upper Ordovician-Devonian sequence that oversteps cratonic North America and several accreted Ordovician terranes (Keppie, 1989). Their eruption overlaps the switch in the sedimentary source from northwest in the Silurian to predominant southeast in the Early Devonian (Hall et al., 1976; Osberg et al., 1989). The southeastern source is inferred to be the Avalon Composite Terrane and locally the Miramichi Highlands. Deposition of these rocks was synchronous with the sinistral accretion of the Avalon Composite Terrane to the eastern margin of the Appalachians (Keppie, 1989). The arrival of SE-derived flysch in the Early Devonian dates the initial accretion of the Avalon Composite Terrane to this part of the Appalachians. Dostal et al. (1989) argued that sinistral accretion of the Avalon Composite Terrane induced oblique extension in the Tobique volcanic belt and this model also appears to be applicable to the Piscataquis volcanic belt. The limited calc-alkali volcanism observed in the Edmunds Hill Formation may be explained by minor subduction at the end of the accretionary process (Keppie et al., 1991). This tectonic setting is generally similar to that envisaged by Laurent and Belanger (1984) and Bedard (1986) and is consistent with the Late Silurian-Early Devonian tectonothermal event associated with the accretion of the Avalon Composite Terrane recorded in the Miramichi Highlands of New Brunswick (van Staal et al., 1990) and in Newfoundland (Dunning et al., 1990).

\section{Conclusions}

The Silurian-Early Devonian basaltic rocks of the Piscataquis volcanic belt are mainly related to intracontinental crustal rifting. The volcanic rocks are bimodal with only minor amounts of intermediate rocks. The continental tholeiites were generated from a heterogeneous subcontinental lithospheric mantle source. The geochemical characteristics and genesis of most of these volcanic rocks are similar to those found in contemporaneous volcanism in the Tobique volcanic belt and in the Gaspé Peninsula (Laurent and Belanger, 1984; Bedard, 1986; Dostal et al., 1989). This rifting is inferred to have been caused by sinistral oblique accretion of the Avalon Composite Terrane to the North America craton (Keppie, 1989). During the terminal stages of accretion limited subduction took place to produce the aerially restricted calc-alkali volcanism in the Edmunds Hill Formation.

\section{ACKNowledgements}

This study was partly supported by grants to R. Hon from the National Research Foundation of the United States of America and to J. Dostal from the Natural Sciences and Engineering Research Council of Canada. It is published with the permission of the Nova Scotia Department of Mines and Energy. We are grateful to the drafting section of the Nova Scotia Department of Mines and Energy for preparation of the figures.

Bedard, J.H. 1986. Pre-Acadian magmatic suites of the southeastern Gaspé Peninsula. Geological Society of America Bulletin, 97, pp. 1197-1191.

Bevier, M.L. and Whalen, J.B. 1989. Tectonic significance of Silurian magmatism in the Canadian Appalachians. Geology, 18, pp. 411-414.

Boucot, A.J. 1968. Silurian and Devonian of the northern Appalachians. In Studies of Appalachian geology: northern and maritime. Edited by E-an Zen, W.S. White, J.B. Hadley, and J.B. Thompson. Interscience Publications, New York, pp. 83-94.

Boucot, A.J., Field, M.T., Fletcher, R., Forbes, W.H., NaYLOR, R.S., and PAVLIDES, L. 1964. Reconnaissance bedrock geology of Presque Isle quadrangle, Maine. Maine Geological Survey, Quadrangle Map Series No. 2, 123 p.

Bradley, D.C. 1983. Tectonics of the Acadian orogeny in New England and adjacent Canada. Journal of Geology, 91, pp. 381-400.

Condie, K.C. 1987. Early Proterozoic volcanic regimes in south- 
western North America. In Geochemistry and Mineralization of Proterozoic Volcanic Suites. Edited by T.C. Pharaoh, R.D. Beckinsale, and D. Rickard. Geological Society Special Publication 23, Blackwell, Oxford, pp. 211-218.

Denning, A.S. and Lux, D.R. 1985. ${ }^{40} \mathrm{Ar} / 3^{9} \mathrm{Ar}$ incremental release dating of two igneous bodies in the Katahdin batholith, northcentral Maine. Geological Society of America, Abstracts with Programs, 17, p. 15.

Dostal, J., Wilson, R.A., and KePPIE, J.D. 1989. Geochemistry of Siluro-Devonian Tobique volcanic belt in northern and central New Brunswick (Canada): tectonic implication. Canadian Journal of Earth Sciences, 26, pp. 1282-1296.

Dunning, G.R., O'Brien, S.J., Colman-Sadd, S., Dickson, W.L., O'Neill, P., and Krogh, T.E. 1990. Silurian orogen in Newfoundland Appalachians. Journal of Geology, 98, pp. 895-913.

Fitzgerald, J.P. 1991. Geochemistry of the Spider Lake and West Branch Penobscot volcanic suites, Northern Maine: Tectonic implications from a complex petrogenesis. M.Sc. thesis, Boston College, 205 p.

HALL, B.A. 1970. Stratigraphy of the southern end of the Munsungun anticlinorium, Maine. Maine Geological Survey Bulletin, 22, 63 p.

Hall, B.A., Pollock, S.G., and Dolan, K.M. 1976. Lower Devonian Seboomook Formation and Matagamon Sandstone, northern Maine: a flysch basin margin delta complex. Geological Society of America, Memoir 148, pp. 57-63.

KePPIE, J.D. 1989. Northern Appalachian terranes and their accretionary history. Geological Society of America, Special Paper 230, pp. 159-192.

Keppie, J.D., Dostal, J., and Hon, R. In press. Silurian-Early Devonian evolution of the northwestern mainland Appalachians. Geology.

Lajoie, J., Lesperance, P.J., and Beland, J. 1968. Silurian stratigraphy and paleogeography of the Matapedia-Temiscouata region, Quebec. American Association of Petroleum Geologists Bulletin, 52, pp. 615-640.

Laurent, R. and Belanger, J. 1984. Geochemistry of SiluroDevonian alkaline basalt suites from the Gaspé Peninsula, Quebec Appalachians. Maritime Sediments and Atlantic Geology, 20, pp. 67-78.

Loiselle, M., Hon, R., and Naylor, R.S. 1983. Age of the Katahdin batholith, Maine. Geological Society of America, Abstracts with Programs, 15, p. 146.

Osbero, P.H., Hussey, A.M., and Boone, G.M. 1985. Bedrock geologic map of Maine. Scale 1:50 000. Maine Geological Survey, Augusta, Maine.

Osbero, P.H., Tull, J.M., Robinson, P., Hon, R., and Butler, J.R. 1989. The Acadian orogen. In The Geology of North America, F-2, pp. 179-232.

Pavlides, L. 1974. General bedrock geology of northeastern Maine. 66th Annual Meeting of the New England Intercollegiate Geological Conference, Orono, Maine, pp. 61-85.

Pearce, J.A. 1983. The role of sub-continental lithosphere in magma genesis at destructive plate margins. In Continental
Basalts and Mantle Xenoliths. Edited by C.J. Hawkesworth and M.J. Norry. Shiva Publishing, Nantwich, pp. 230-249.

Rankin, D.W. 1968. Volcanism related to tectonism in the Piscataquis volcanic belt, an island arc of early Devonian age in north-central Maine. In Studies of Appalachian geology: northern and maritime. Edited by E-an Zen, W.S. White, J.B. Hadley, and J.B. Thompson. Interscience Publications, New York, pp. 83-94.

RankIN, D.W. and HoN, R. 1987. Traveler Rhyolite and overlying Trout Valley Formation and the Katahdin pluton: a record of basin sedimentation and Acadian magmatism, north-central Maine. Geological Society of America, Centennial Field Guide - Northeastern Section, pp. 293-301.

Richter, D.A. and Roy, D.C. 1976. Prehnite-pumpellyite facies metamorphism in central Aroostook County, Maine. Geological Society of America, Memoir 146, pp. 183-261.

Roy, D.C. 1989. The Depot Mountain Formation: transition from syn- to post-Taconian basin along the Baie Verte-Brompton Line in northwestern Maine. Studies in Maine Geology, Maine Geological Survey, 2, pp. 85-99.

Roy, D.C. and MENCher, E. 1976. Ordovician and Silurian stratigraphy of northeastern Aroostock County, Maine. Geological Society of America, Memoir 148, pp. 25-42.

Sargent, S.L. 1985. Petrology and geochemistry of the volcanic rocks of the Dockendorff Group and the Munson pluton, northeastern Maine. M.Sc. thesis, Boston College, 150 p.

Schwartz, W.D. 1991. Trace element geochemistry of the Silurian alkali basalt magmatism in northern Maine. M.Sc. thesis, Boston College.

Shervais, J.W. 1982. Ti-V plots and the petrogenesis of modem and ophiolitic lavas. Earth and Planetary Science Letters, 57. pp. 101-118.

Sun, S.S. and McDonough, W.F. 1989. Chemical and isotopic systematics of oceanic basalts: implications for mantle processes. In Magmatism in the Ocean Basins. Edited by A.D. Saunders and M.J. Norry. Geological Society Special Publication 42, Blackwell, Ox ford, pp. 313-345.

ThiRwALL, M.F. 1988. Wenlock to mid Devonian volcanism of the Caledonian-Appalachian orogen. In Caledonian-Appalachian Orogen. Edited by A.L. Harris and D.J. Fettes. Geological Society Special Publication 38, Blackwell, Oxford, pp. 415-428.

van StaAl, C.R., Ravenhurst, C.E., Winchester, J.A., RodDiCK, J.C., and LANGTON, J.P. 1990. Evidence for a postTaconic blueschist suture in northern New Brunswick, Canada. Geology, 18, pp. 1073-1077.

White, K.J. and RoY, D.C. 1975. Mapleton Formation: an immediately post-Acadian basin fill. Geological Society of America, Abstracts with Programs, 7, p. 133.

WILson, M. 1989. Igneous Petrogenesis. Unwin Hyman, London, $466 \mathrm{p}$.

Winchester, J.A. and Floyd, P.A. 1977. Geochemical discrimination of different magma series and their differentiation products using immobile elements. Chemical Geology, 20, pp. 325-343. 